\title{
A SEMI-AUTOMATED BONE PRETREATMENT SYSTEM AND THE PRETREATMENT OF OLDER AND CONTAMINATED SAMPLES
}

\author{
I A LAW and R E M HEDGES
}

Oxford Radiocarbon Accelerator Unit, Research Laboratory for Archaeology and the History of Art, University of Oxford, 6, Keble Road, Oxford OX1 3 QJ, United Kingdom

\begin{abstract}
A semi-automated continuous-flow system used to process archaeological bone to purified gelatin or amino acids for ${ }^{14} \mathrm{C}$ dating is described. Powdered bone is retained in flow cells specifically designed to permit the sequential leaching of the bone with acid, alkali and water. Crude collagen obtained by this process is gelatinized, and than either purified directly using a macroporous cation exchange resin (BioRad AGMP-50), or hydrolyzed and the amino acids desalted on BioRad 50W-X8 resin. When compared with previous methods used by the laboratory, the new method allows more samples to be treated to a higher degree of purification. Examples of dates obtained on "standard" bones are presented, and confirm that no contamination is introduced from the components used in the new process.
\end{abstract}

\section{INTRODUCTION AND AIMS}

It is always advisable to handle samples and sample vessels as little as possible during a chemical routine in order to reduce time, tedium and contamination. When a routine is repetitive and applied to multiple samples, these problems increase. For these reasons, chemical pretreatment of archaeological bone samples developed by Gillespie, Hedges and Humm (1986), and used routinely in our laboratory for up to 12 samples, was found unsuitable for scaling-up to deal with 18-20 samples. Several centrifuging and decanting steps required for each sample made the procedure laborintensive. Thus, it appeared that increased sample output could only be achieved by developing a semi-automated process where samples contained in flow cells could be exposed sequentially to the appropriate solutions with minimum operator intervention. The success of this system enabled us to incorporate further purification steps into our routine chemistry procedure without increasing time and effort to produce a combustion sample.

\section{THE FLOW-CHEMISTRY SYSTEM} lows:

The individual components of the continuous-flow system are as fol-

1) The flow cell and cell-top assembly. The glass sample cells are constructed from $22 \mathrm{~mm}$ od "SVL" threaded tubes and are tapered to form a cone as shown in Figure $1 \mathrm{~b}$. The internal volume of the cell is $9 \mathrm{~cm}^{3}$, suitable for samples of crushed bone between $0.3-1.5 \mathrm{~g}$. The cell top is constructed from glass-loaded PTFE, and the inlet and outlet ports are threaded to accept "Omnifit" connector valves (Fig 1a). Pretreatment solutions are introduced through the inlet port and directed to the bottom of the cell by a length of glass or PTFE tubing. Liquids reaching the sample in this way are forced to permeate upwards and spread outwards through the material such that the upward velocity of the solution decreases as the width of the conical 


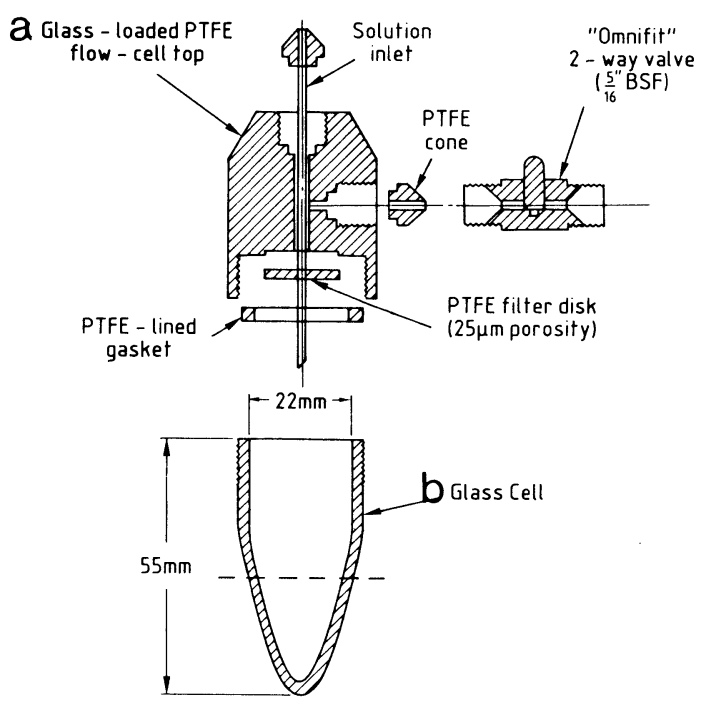

Fig 1. Bone chemistry flow cell

section increases. This effect reduces disturbance to the sample and increases the efficiency of the collagen extraction and purification. Solution that has permeated the sample moves upwards through a "void" space and exits from the cell outlet port via a porous PTFE filter disk. The "void" space is necessary to prevent the porous disk from becoming clogged by particulate materials, but should be kept as small as possible to obtain maximum efficiency of solution exchange.

2) The pumps and pump tubing. The pumps are 24-channel peristaltic models, constructed by "Ismatec." Solutions are pumped through "Tygon" PVC auto-analyzer tubes and are held in cartridges that can be adjusted or isolated individually.

3) "Omnifit" connectors and tubes. Connections between the solution reservoirs, pump tubing and cells are made with $1.6 \mathrm{~mm}$ od, $0.5 \mathrm{~mm}$ id PTFE tubing via "Omnifit" connectors (also made of PTFE). These are totally inert to the solutions used.

4) Solution reservoirs. These are of various volumes $(1.0-3.0 \mathrm{~L})$, with a common threaded neck size of $45 \mathrm{~mm}$. "Omnifit" tops equipped with valved ports are used to connect these to the solution distribution manifolds.

5) The time-based controller. This is a microprocessor-based instrument with four independently operable mains outputs, allowing the automatic activation of up to four pieces of equipment. It is used to switch on (or off) the preset peristaltic pumps, and also the fraction collector, if the acid- or alkali-soluble fractions of the samples are required. The switching sequence for any particular run is entered into the memory of the controller using a membrane key pad.

6) The fraction collector. As far as we are aware, the only fraction collector capable of receiving solutions from up to 20 channels simultaneously is the LKB "Ultrorac II" model 2070. As indicated above, this can be used 
to collect the acid, water and alkali wash solutions from each individual cell, and ensures that fractions other than those derived from insoluble "collagen" can also be investigated.

\section{USING THE FLOW-CHEMISTRY SYSTEM}

The flow cell top assembly (Fig 1a) is prepared. The porous disk is punctured at the center to allow the solution-delivery tube to be inserted into the cell. The delivery tube is equipped with a PTFE cone or ferrule to ensure that no solution leaks from the inlet port. When the tube and filter disk are in position, the PTFE-coated "O" ring is inserted into the cap, and the cell containing the weighed sample mixed with $4 \mathrm{~cm}^{3}$ of demineralizing acid is screwed into position. This is repeated for all of the samples, and these are then placed into the sample holder on the continuous-flow rig.

The reservoirs are filled with the appropriate solutions and the distribution manifolds are primed. The flow rate of each pump is preset, and solutions are pumped through for a short period to remove air or solution remaining from a previous run. One line from each pump is connected to a four-way distribution fitting (Omnifit), and the remaining port of the fitting is connected to a cell inlet valve. A length of tubing is attached to the cell outlet, which is taken either to the fraction collector or to waste. An appropriate program is entered into the controller, and the apparatus is left to run (usually overnight). Table 1 shows an example of the amounts of solution and the operating flow rates required for a typical run.

TABLE 1

The chemistry: A typical program to obtain "collagen" for $0.3-1.0 \mathrm{~g}$ of sample

\begin{tabular}{lcccc}
\hline Process & $\begin{array}{c}\text { Flow rate } \\
(\mathrm{ml} / \mathrm{min})\end{array}$ & $\begin{array}{c}\text { Cell vols } \\
\text { used }\end{array}$ & $\begin{array}{c}\text { Total vol } \\
\text { used }(\mathrm{ml})\end{array}$ & $\begin{array}{c}\text { Time } \\
(\mathrm{hr}: \mathrm{min})\end{array}$ \\
\hline Demineralization $(0.5 \mathrm{M} \mathrm{HCl})^{*}$ & 0.3 & 10 & 90 & $5: 00$ \\
Water rinse & 0.6 & 10 & 90 & $2: 30$ \\
NaOH rinse (0.1M) & 0.6 & 4 & 36 & $1: 00$ \\
Water rinse & 0.6 & 12 & 108 & $3: 00$ \\
Acid (to pH 3) & 0.3 & - & 0.3 & $0: 01$ \\
Water & 0.6 & - & 1.2 & $0: 02$ \\
& & & Total time ca 11:00 \\
\hline
\end{tabular}

* This can incorporate stop-flow periods to aid equilibration.

A gelatinization stage similar to that recommended by Longin (1971) and by Protsch (1975) is now given to every sample of crude "collagen" obtained from the continuous-flow procedure. This is done on the samples while they are still in the flow cells, by removing them from the rig, closing the inlet and outlet valves, and placing them in a hot-block at $100^{\circ} \mathrm{C}$ until the protein is dissolved (usually $<12 \mathrm{hr}$ ). When the cells are cooled, the gelatin solution is removed by inverting them and applying pressurized air to the inlet valve. 


\section{IMPROVEMENTS TO THE CHEMICAL PURIFICATION OF BONE PROTEIN}

Hydrolysis of proteins in the presence of other organic substances produces artifacts (Hunt, 1985), which cannot always be removed by subsequent purification procedures. Archaeological "collagen" often contains humictype materials which, in turn, contain proteinaceous and polysaccharide residues (Aiken et al, 1985). Hydrolysis of collagen in the presence of humic materials could thus contribute soil-derived amino acids to the hydrolyzate, which would be inseparable from the same amino acids derived from the bone. Sugars released from polysaccharides would react with amino acids in the hydrolyzate, leading to "humin" formation and "browning" reactions, where amino acids and sugar molecules combine. Stafford et al $(1982,1987)$ have used XAD-2 resin to remove color attributed to humic-derived contaminants after hydrolysis, but it would be preferable to remove this contamination before hydrolysis. Gelatinization helps remove the insoluble soilderived humin and high molecular weight humic acids, but it does not necessarily produce a solution of pure protein. Thus, we investigated the macroporous cation exchange resin BioRad AGMP-50 as a means of purifying gelatin solutions prior to hydrolysis. This is essentially a macroporous version of BioRad 50W-X8, which we have used traditionally in the purification of amino acids from collagen hydrolyzates. Samples of up to $40 \mathrm{mg}$ of crude gelatin are applied as a solution at $\mathrm{pH} 3.0$ to a column containing $6 \mathrm{~cm}^{3}$ of resin in the $\mathrm{H}^{+}$form. Excess salt and other contaminants are washed out with distilled water, and purified gelatin is eluted with 2 column volumes of 1.5 $\mathrm{M} \mathrm{NH}_{4} \mathrm{OH}$ solution. Table 2 lists some results pertaining to the use of this material. Generally, crude- or ion-exchanged gelatin $(15 \mathrm{mg})$ is hydrolyzed

TABLE 2

Data relevant to BioRad AGMP-50 cation-exchange resin

\begin{tabular}{|c|c|c|c|}
\hline \multicolumn{4}{|l|}{ Sample recovery } \\
\hline & $\begin{array}{l}\text { Weight applied } \\
\left(\mathrm{mg} \text { in } 4 \mathrm{~cm}^{3} \mathrm{H}_{2} \mathrm{O}\right)\end{array}$ & $\begin{array}{l}\text { Weight recovered } \\
(\mathrm{mg})\end{array}$ & $\%$ recovery \\
\hline $\begin{array}{l}\text { HMS Mary Rose } \\
\text { crude gelatin }\end{array}$ & 19.8 & 16.6 & 84 \\
\hline $\begin{array}{l}\text { Bidwell Anglo-Saxon } \\
\text { crude gelatin }\end{array}$ & 20.3 & 17.2 & 85 \\
\hline $\begin{array}{l}\text { Modern bovine } \\
\text { crude gelatin }\end{array}$ & 9.9 & 6.7 & 67 \\
\hline \multicolumn{4}{|l|}{ Dating } \\
\hline & \multicolumn{2}{|l|}{ Fraction } & Age (1б вP) \\
\hline \multirow[t]{2}{*}{ Bidwell Anglo-Saxon } & \multicolumn{2}{|c|}{ Amino acids from crude gelatin } & $1460 \pm 60$ \\
\hline & \multicolumn{2}{|l|}{ Ion-exchanged gelatin } & $1490 \pm 70$ \\
\hline \multirow[t]{2}{*}{ Combe Saunière I } & \multicolumn{2}{|c|}{ Amino acids from crude gelatin } & $17,330 \pm 180$ \\
\hline & \multicolumn{2}{|c|}{$\begin{array}{l}\text { Amino acids from AGMP-50 } \\
\text { purified gelatin }\end{array}$} & $17,550 \pm 200$ \\
\hline
\end{tabular}


in $1 \mathrm{~cm}^{3}$ of $6 \mathrm{M} \mathrm{HCl}$ at $100^{\circ} \mathrm{C}$ overnight. After hydrolysis, the $\mathrm{HCl}$ is removed by heating under vacuum, the amino acids are redissolved in $1.5 \mathrm{~cm}^{3}$ of distilled water and applied to a column containing $6 \mathrm{~cm}^{3}$ of $50 \mathrm{~W}-\mathrm{X} 8$ resin in the $\mathrm{H}^{+}$form. If required, hydrolyzates are clarified with charcoal or with BioBeads SM-2 (the BioRad equivalent of XAD-2 resin) before ion exchange. As for gelatin, the excess salts and contaminants are washed out of the column with distilled water, and the sample eluted in 2 column volumes of $1.5 \mathrm{M} \mathrm{NH}_{4} \mathrm{OH}$. The full list of pretreatment options available to us are summarized in Table 3 .

\section{TABLE 3}

The chemistry: purification of "collagen" to obtain a dating sample*

1. Gelatinize "collagen" in flow cells

2. Filter gelatin out of cells using compressed air

**3. Purify gelatin solution: ion-exchange (BioRad AGMP-50 resin)

${ }^{* *} 4$. Hydrolyze and purify amino acids: 1$)$ dry; 2) hydrolyze $\left(6 \mathrm{M} \mathrm{HCl}, 100^{\circ} \mathrm{C}\right.$, overnight); 3) ion-exchange (BioRad 50W-X8 resin)

5. Dry and burn

* The combination of steps $1,2,4$ and 5 now constitute our routine pretreatment

** Optional

\section{EXAMPLES OF RESULTS OBTAINED BY THE CONTINUOUS-FLOW METHOD}

The following bone samples are used to assess the accuracy of our dating as well as laboratory contamination:

Pig bone from HMS Mary Rose

Alaska whale bone

- expected age,

- expected age,

Bidwell Anglo-Saxon

- expected age,

310 BP

$>45,000$ BP $\simeq 1500 \mathrm{BP}$

Table 4 lists ${ }^{14} \mathrm{C}$ ages obtained for these samples by our previous batch method and by the continuous-flow technique. Results obtained for a dupli-

TABLE 4

A comparison of dates obtained by using the batchwise chemical preparation method of Gillespie, Hedges and Humm (1986) and the continuous flow method described in this paper. All continuous flow dates are on hydrolyzed gelatin, except for OXA-1236, which was ion-exchanged unhydrolyzed gelatin.

\begin{tabular}{lcc}
\hline & \multicolumn{2}{c}{${ }^{14} \mathrm{C}$ age $(1 \sigma \mathrm{BP})$} \\
\hline HMS Mary Rose & Batch & Continuous flow \\
Alaska & $304 \pm 25^{*}$ & $330 \pm 22^{* *}$ \\
Bidwell & $>45,000$ & $>45,000$ \\
Anglo-Saxon & $1570 \pm 80($ OXA-771) & $1478 \pm 38($ OXA-1233, \\
Combe Saunière & $1550 \pm 80($ OXA-772) & $-1235,-1236)$ \\
& $17,700 \pm 290($ OXA-488) & $17,550 \pm 200($ OXA-1252) \\
& & $17,330 \pm 180($ OXA-1253)
\end{tabular}

${ }^{*}$ Mean of six dates (Hedges et al, 1987)

** Mean of eight dates 
cate treatment on a bone from Combe Saunière (excavated By J-M Geneste, 1978) are also reported.

\section{DISCUSSION AND CONCLUSION}

${ }^{14} \mathrm{C}$ laboratories that date archaeological bones should extract the most representative sample possible from the material submitted. Stafford et al (1987) provide a reference list of recent reports on the development of these techniques, as well as recommendations for comprehensive pretreatment. The practical procedures required to obtain pure samples are often complicated and labor-intensive and, as such, are unlikely to be adopted for routine use. We have described a system that overcomes these difficulties and allows for the application of various levels of purification. The results reported in Table 4 show that no sample contamination occurs during the flow-chemistry processing.

The macroporous cation exchange resin BioRad AGMP-50 is introduced as a material for use in the purification of gelatin solutions. We hope that more results relevant to the use of this resin will be reported later. However, preliminary results show that high sample recoveries are possible and that no contamination from the resin is observed.

\section{ACKNOWLEDGMENTS}

The authors thank M J Humm for scientific and technical help, and D Seeley for manufacturing the flow-cell tops. The Radiocarbon unit is supported mainly by the SERC.

\section{Note Added in Proof}

The system described in the text has been modified to run on one multichannel pump by interfacing a BBC model B microcomputer to the pump and to three inert, electrically actuated, valves. Each valve controls the flow of one particular solution. The rate of pumping is variable, and is also controlled by the microcomputer. Using appropriate programs, the continuous-flow apparatus has been used successfully in the pretreatment of wood and linen to cellulose, and for the purification of charcoal samples. However, the use of continuous-flow techniques in the pretreatment of these materials is not yet routine.

\section{REFERENCES}

Aiken, G R, McKnight, D M, Wershaw, R L and MacCarthy, P, 1985, Humic substances in soil, sediment, and water, in Geochemistry, isolation and characterization: New York, John Wiley \& Sons

Gillespie, R, Hedges, R E M and Humm, M J, 1986, Routine AMS dating of bone and shell proteins, in Stuiver, $\mathrm{M}$ and Kra, R S, eds, 12 th internatl ${ }^{14} \mathrm{C}$ conf, Proc: Radiocarbon, $\mathrm{v} 28$, no. $2 \mathrm{~A}, \mathrm{p} 451-456$.

Hedges, R E M, Housley, R A, Law, I A, Perry, C and Gowlett, J A J, 1987, Datelist 6: Archaeometry, v 29, no. 2, p 289-306.

Hunt, S, 1985, Degradation of amino acids accompanying in vitro protein hydrolysis, in Barrett, G C, ed, Chemistry and biochemistry of the amino acids: London, Chapman and Hall, p 376-398. 
Longin, R, 1971, New method of collagen extraction for radiocarbon dating: Nature, v 230, p 241-242.

Protsch, R, 1975, The absolute dating of Upper Pleistocene Sub-Saharan fossil hominids and their place in human evolution: Jour Human Evolution, v 4, p 297-322.

Stafford, T W, Jr, Duhamel, R C, Haynes, C and Brendel, K, 1982, Isolation of proline and hydroxyproline from fossil bone: Life Science, v 31, p 931-938.

Stafford, T W, Jr, Jull, A J T, Brendel, K, Duhamel, R C, and Donahue, D, 1987, Study of bone radiocarbon dating accuracy at the University of Arizona NSF Accelerator Facility for Radioisotope Analysis: Radiocarbon, v 29, no. 1, p 24-44. 